\title{
Heavy metals in sediments of Ganga River: up- and downstream urban influences
}

\author{
Jitendra Pandey ${ }^{1} \cdot$ Rachna Singh $^{1}$
}

Received: 1 April 2015/Accepted: 25 August 2015/Published online: 5 September 2015

(C) The Author(s) 2015. This article is published with open access at Springerlink.com

\begin{abstract}
Bottom sediment in a river often acts as a sink and indicator of changes in water column and magnitude of anthropogenic influences through air and watersheds. Heavy metal concentration in sediments of Ganga River was studied along a $37-\mathrm{km}$ stretch to assess whether there is a significant difference between sites situated upstream and downstream of Varanasi urban core. Metal concentration increased consistently along the study gradient, indicating the influence of urban sources. Concentration in the river sediment was found highest for Fe followed by $\mathrm{Mn}, \mathrm{Zn}, \mathrm{Cr}, \mathrm{Cu}, \mathrm{Ni}, \mathrm{Pb}$, and $\mathrm{Cd}$. Mann-Kendall trend analysis showed marked seasonality in the concentration with values being highest in summer and lowest in rainy season. Enrichment factor revealed severe enrichment of $\mathrm{Cd}$ and $\mathrm{Pb}$ at downstream sites, and principal component analysis segregated sites into four distinct groups indicating source relationships. Concentrations of $\mathrm{Cd}, \mathrm{Pb}, \mathrm{Ni}, \mathrm{Cu}$, and $\mathrm{Cr}$ did exceed WHO standards. The study has relevance designing control measures and action plans for reducing sediment contamination in anthropogenic impacted rivers.
\end{abstract}

Keywords Atmospheric deposition · Ganga River basin . Enrichment factor $\cdot$ Heavy metal $\cdot$ Sediment

Jitendra Pandey

jiten_pandey@rediffmail.com

Rachna Singh

rachna_singh99@yahoo.co.in

1 Ganga River Ecology Research Laboratory, Environmental Science Division, Centre of Advanced Study in Botany, Banaras Hindu University, Varanasi 221005, India

\section{Introduction}

During latter part of the twentieth century, India witnessed rapid urban-industrial growth and increased food production to meet the requirements of rapidly growing population. As a result, the surface water bodies receive massive amount of pollutants including heavy metals. The input of heavy metals in surface waters has particular concern due to their toxic nature. After entering to water bodies, metals accumulate in water, sediments, and biota. Sediments are regarded as ultimate sink and indicator of changes in water column as well as the influence of anthropogenic activities in air and watersheds (Ramesh et al. 1990). Heavy metals of anthropogenic origin enter into the rivers as inorganic complexes or hydrated ions, which are easily adsorbed on surface of sediment particles and constitute the labile fraction (Vukovic et al. 2014). Environmental and ecosystem variables such as turbulence, water $\mathrm{pH}$, redox potential, seasonal flooding, and storms cause periodic remobilization of contaminated surface and thereby making the bottom sediments a potential source (Osakwe et al. 2014). Previous studies have shown that $30-98 \%$ of heavy metals in rivers are transported in sediment-associated forms (Wang et al. 2011).

Metals entering into the river through natural processes such as weathering, erosion, and dissolution of water-soluble salts constitute the background level, but those added through anthropogenic activities substantially enhance the concentrations in sediment (Rzetala 2015). Being nonbiodegradable, metals accumulate in sediments and in biota across the food chain leading to long-term ecosystem level effect. Benthic organisms which are under direct contact with sediments are more prone to such exposures. Some of the metals such as $\mathrm{Pb}$ and $\mathrm{Cd}$ are nonessential and are harmful even at very low concentrations (Pehlivan et al. 
2009). The secondary contamination of water column affects plankton (Copaja et al. 2014), and a food chainassociated transfer may eventually cause adverse effects to human health. The river channels close to urban center receive heavy metals from both natural and anthropogenic sources including industrial release, domestic wastes, and municipal sewage. In addition, metals in airborne particulates reach directly through atmospheric deposition and indirectly through surface runoff (Pandey et al. 2013). Ghrefat et al. (2011) showed that high concentrations of $\mathrm{Pb}, \mathrm{Cd}$, and $\mathrm{Zn}$ in sediments of Kafrain dam, at the confluence of a small perennial stream with Jordan valley, were associated with anthropogenic activities. Studies conducted in India have indicated rising levels of heavy metals in river sediments (Singh et al. 2005; Dhanakumar et al. 2011; Kumar et al. 2013).

The Indo-Gangetic plain is a densely populated region and one of the largest groundwater repositories on the earth. Alarming population growth, unplanned urbanization, and industrialization in the region have become the cause of concern for rising level of heavy metals in Ganga River (Singh et al. 2005; Singh and Pandey 2014). Despite the fact that the input of heavy metals in Ganga River is continuously rising (Pandey et al. 2010), data on heavy metal contamination of freshly deposited sediments of the river are very scarce. During recent years, Varanasi city witnessed massive expansion without meeting technical standards of roads, sewage treatment, garbage collection, and urban drainage. As a result, the river along urban segment receives large amount of organic and inorganic pollutants including heavy metals. The newly established Ministry of Water Resources, River Development and Ganga Rejuvenation by Government of India, may warrant long-term studies on these issues to understand the magnitude of contamination and source relations. In this study, freshly deposited sediment of Ganga River was analyzed for eight heavy metals to evaluate their spatial distribution in the sediments. In particular, the main focus was to explore the possible influence of urban core and other sources of metal input to the river.

\section{Materials and methods}

\section{Study area}

This study was conducted during March 2012-February 2013 at nine study sites along a 37-km stretch of the Ganga River covering upstream to downstream urban core of Varanasi $\left(25^{\circ} 18^{\prime} \mathrm{N}\right.$ lat. and $83^{\circ} 1^{\prime} \mathrm{E}$ long.). Sites were selected on the basis of catchment characteristics and sources of input. Sites 1 and 2 are relatively natural, and the rest of the sites are invariably human influenced (Fig. 1; Table 1). The river along the city receives sewage from the Nagwa drain located upstream to Assi Ghat, Shivala drain located between Assi Ghat and Dashashwamedh Ghat, and Khirki drain situated downstream Rajghat. Climate of the region representing the study location (Fig. 1) is tropical with distinct seasons; a hot and dry summer (April-June), warm and wet rainy season (July-September), and a cool and dry winter (November-February). The region received 40, 36, and $768 \mathrm{~mm}$ rainfall during winter, summer, and rainy season, respectively. Mean respective temperature for these seasons ranged from 7.4-31.4, 18.7-43 to 21-36. $9^{\circ} \mathrm{C}$. October and March represent transition months. In summer, the temperature sometimes exceeds $46{ }^{\circ} \mathrm{C}$. More than $90 \%$ of the average annual rainfall $(1050 \mathrm{~mm})$ occurs in rainy season (Singh 2012). Wind direction shifts predominantly westerly to southwesterly in October to April and easterly to northwesterly in remaining months. The study area lies in the Indo-Gangetic plains characterized by a variety of land forms and drainage systems and fertile alluvial fluvisol associated with recurrent floods or long wetness. This vast alluvial plain separates the Himalayan ranges in north from Peninsular India in south. The northern margin of the plain is marked by the exposure of Siwalik rocks, while the southern margin is irregular and shows out crops of rocks protruding the alluvium at many places. The Ganga plain, which appears as a flat alluvial plain, is a shallow asymmetrical depression with a gentle easterly gradient. The drainage basin of Ganga River occupies an area of $1.08 \times 10^{6} \mathrm{~km}^{2}$. Over $60 \%$ of water flowing into Ganga plain comes from the Himalayan sources while about $40 \%$ from the peninsular region. The fore land basin sediments rest on a gently north sloping basement made up of metamorphosed rock succession of Precambrian age or Late Proterozoic or Gondwana sediments (Singh 1996).

\section{Sampling and analysis}

Sediment samples $(0-10 \mathrm{~cm}$ depth) from each site were collected using sediment core sampler every month in triplicates for the analysis of eight heavy metals. Samples were air-dried at room temperature, homogenized, and sieved using a 2-mm mesh sieve. Samples were digested in tri-acid mixture $\left(\mathrm{HNO}_{3} / \mathrm{HCl} /\right.$ Perchloric acid: 5:1:1) at $85{ }^{\circ} \mathrm{C}$ on a hot plate and analyzed using atomic absorption spectrophotometer (PerkinElmer model Analyst 800, USA). The detection limit of the instrument is $5(\mathrm{Fe}), 1.5$ $(\mathrm{Zn}), 15(\mathrm{~Pb}), 6(\mathrm{Ni}), 1.5(\mathrm{Mn}), 1.5(\mathrm{Cu}), 0.8(\mathrm{Cd})$, and $3 \mu \mathrm{g} \mathrm{L}^{-1}(\mathrm{Cr})$. The organic carbon (OC) in the sediments was measured following Walkley and Black (1947) method. 


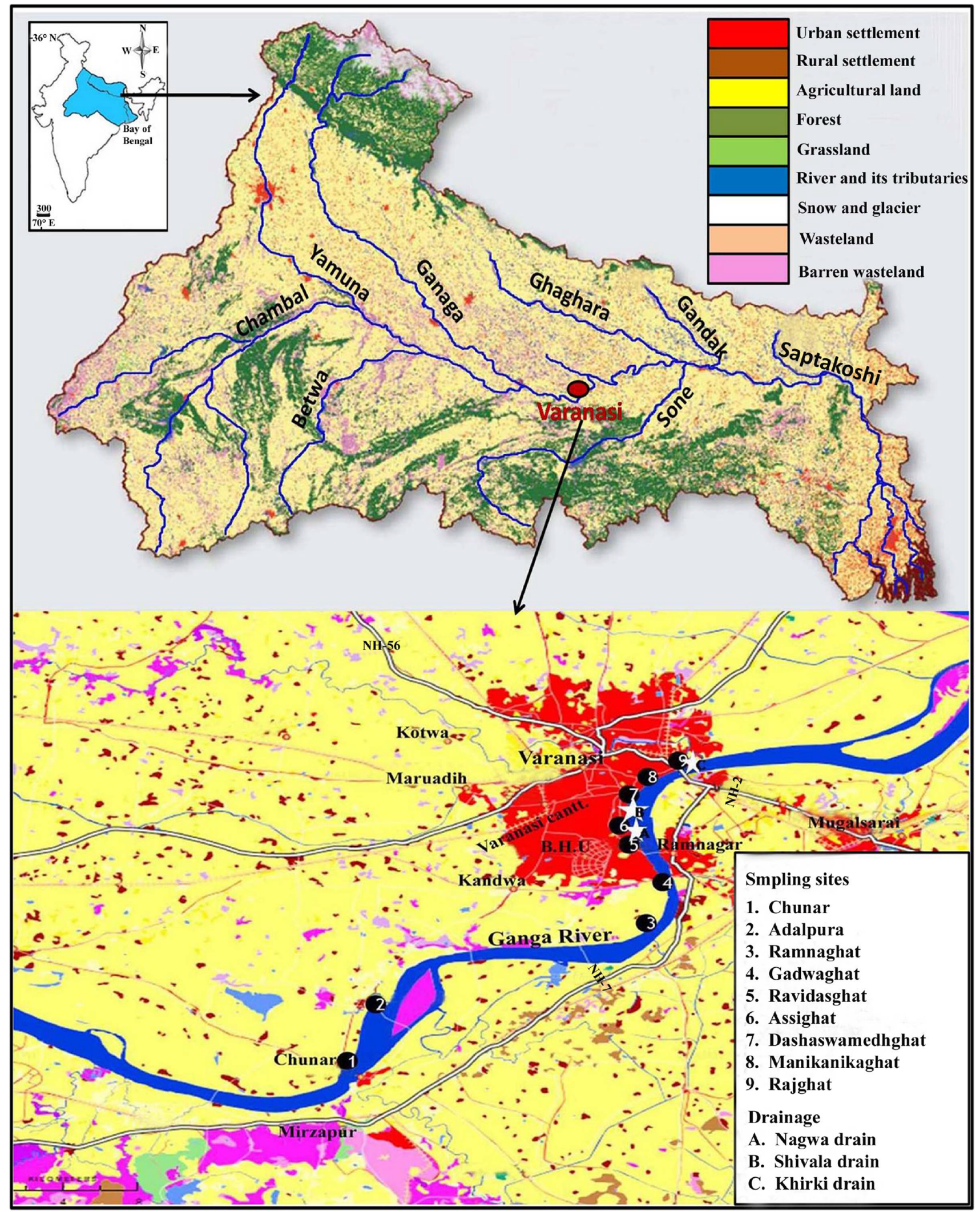

Fig. 1 Map showing study sites in the Ganga River 
Table 1 Description of sampling sites and source characteristics

\begin{tabular}{|c|c|c|}
\hline Site no. & Sampling site & Features \\
\hline 1 & Chunar & Rural/suburban type agglomeration \\
\hline 2 & Adalpura & Rural settlement \\
\hline 3 & Ramna Ghat & Agricultural land \\
\hline 4 & Gadwa Ghat & $\begin{array}{l}\text { Agricultural land and bypass } \\
\text { highway }\end{array}$ \\
\hline 5 & Ravidas Park & Core urban \\
\hline 6 & Assi Ghat & Urban settlement \\
\hline 7 & $\begin{array}{l}\text { Dashashwamedh } \\
\text { Ghat }\end{array}$ & Core urban settlement \\
\hline 8 & Manikarnika Ghat & Core urban \\
\hline 9 & Rajghat & Urban, Malviya bridge highway \\
\hline
\end{tabular}

\section{Percent enrichment}

To evaluate the extent of metal pollution, concentrations measured at various sites are subtracted from their pre-industrial level or concentrations in an area which is free of such contamination and has same origin, mineralogy and grain size. In practice, this task is difficult, and therefore, a reference value with less restrictive criteria is used (Zonta et al. 1994). Based on this assumption, we calculated percentage enrichment factor considering the lowest figure obtained in this study as a reference value. Accordingly, the percent enrichment was calculated following Zonta et al. (1994) as below:

Percent enrichment $\%=\frac{C-C_{\min }}{C_{\max }-C_{\min }} \times 100$

where $C$ is the mean concentration $\left(\mu \mathrm{g} \mathrm{g}^{-1}\right)$ in sediment, $C_{\min }$ and $C_{\max }$ are the minimum and maximum concentrations $\left(\mu \mathrm{g} \mathrm{g}^{-1}\right)$ observed in this study. This measure gives the ratio of concentration of a given heavy metal in sediment to its corresponding background value.

\section{Enrichment factor (EF)}

The enrichment factor (EF) is used to assess the level of contamination and possible anthropogenic impact. For geochemical normalization of metal data, normalized concentration of a conservative element, such as $\mathrm{Al}, \mathrm{Fe}$, or $\mathrm{Si}$, is generally employed (Mucha et al. 2003). The Fe, which is considered in this study, is a commonly used and well-authenticated conservative tracer for differentiating metal sources variability (Mucha et al. 2003; Esen et al. 2010; Ghrefat et al. 2011). The EF was calculated following Ghrefat et al. (2011) as below:

$\mathrm{EF}=\frac{(\mathrm{M} / \mathrm{Fe})_{\text {sample }}}{(\mathrm{M} / \mathrm{Fe})_{\text {background }}}$

where $(\mathrm{M} / \mathrm{Fe})_{\text {sample }}$ is the ratio of metal and Fe concentration of the sample, and $(\mathrm{M} / \mathrm{Fe})_{\text {background }}$ is the ratio of metal and background $\mathrm{Fe}$ concentration. The background concentrations of $\mathrm{Fe}, \mathrm{Zn}, \mathrm{Ni}, \mathrm{Mn}, \mathrm{Pb}, \mathrm{Cd}, \mathrm{Cu}$, and $\mathrm{Cr}$ are based on Singh et al. (2003) which is recalculated for Ganga River sediment from Turekian and Wedepohl (1961). For such calculations, pristine values are generally used. For most of the Indian scenario and for the present study region however, pristine values are not available. Therefore, the background concentrations computed by Singh et al. (2003) were used for relative understanding of metal enrichment.

\section{Statistical analysis}

Correlation analysis was employed to assess linearity in relationship between variables. SPSS (Statistical Package for the Social Sciences) version 16 was used for the analysis. Mann-Kendall test and Sen's slope estimator (XLSTAT 2014) were used for detecting trend direction and magnitude of changes along the sites. Principal component analysis (PCA) was performed using PAST software.

\section{Results and discussion}

Contamination of sediments is one of the emerging environmental issues in India. In river systems, sediment contributes both as a source and a sink of heavy metals depending upon water chemistry, river flow, and the level of saturation relative to overlying water column. Sources such as urban discharge, industrial effluents, and agricultural runoff enhance sediment metal levels in receiving water bodies. In the present study, metal concentrations increased consistently down the study gradient and were highest at site 9. Seasonally, metal concentrations in general were highest in summer followed by winter and rainy season (Fig. 2a-h). In summer at site 1, concentrations of $\mathrm{Fe}, \mathrm{Zn}, \mathrm{Ni}, \mathrm{Mn}, \mathrm{Pb}, \mathrm{Cd}, \mathrm{Cu}$, and $\mathrm{Cr}$ were 35,623.2, 61.7, $14.9,282.1,14.9,1.3,15.4$, and $54.9 \mu \mathrm{g} \mathrm{g}^{-1}$, respectively. The respective concentrations at site 9 were 41,170.1, 92.5, 44.9, 43.0, 32.6, 71.1, 40.8, and $93.3 \mu \mathrm{g} \mathrm{g}^{-1}$. Concentrations at site 2 were almost comparable to the values observed at site 1 . Sites 1 and 2 are located in city upstream and receive rural and suburban influences. Downstream sites with urban influences showed concentrations higher by 1.8 - to 4.10 -fold.

As the river flow declines in summer, the rate of sedimentation and consequently the concentration is enhanced. In rainy season, on the other hand, increased river flow causes a dilution effect, and consequently, metal concentration in sediment declines. Although at the onset of rainy season the first flush effect may enhance the concentration, the dilution effect predominates as the season progresses. 
When concentrations were regressed with river discharge, significant negative relationships observed, indicating that the increased river discharge (from an average $445 \mathrm{~m}^{3} \mathrm{~s}^{-1}$ in summer to over $10,744 \mathrm{~m}^{3} \mathrm{~s}^{-1}$ in rainy season) reduces metal concentration in rainy season. Higher concentrations in winter than rainy season (Fig. 2a-h) could be linked similarly to decreased river flow during winter. While these results are difficult to directly translate to a basin level causation, they highlight the importance of precipitationlinked runoff reducing monsoon season metal levels in Ganga River sediments. Similar seasonal patterns have been reported by Kumar et al. (2013). On spatial scale, a rising trend was observed along the pollution gradient irrespective of season (Fig. 2; Table 2). Mann-Kendall time series analysis with Sen's slope statistics (Fig. 3a-h) showed significant seasonality and a rising trend along the study gradient, indicating the influence of local control. Such trend could be expected due to urban releases of sewage and industrial effluents together with agricultural runoff. Further, the atmospherically deposited substances also reach the river directly or indirectly through land surface runoff (Pandey et al. 2013). Highest concentrations of heavy metals at site 9 indicate a possible effect of these sources. Relatively sharp increase in the concentration of heavy metals, especially $\mathrm{Mn}$ and $\mathrm{Cu}$ at site 3 , seemed to be due to wastewater, in addition to domestic and agricultural causation, flushed from Bhagwanpur sewage treatment plant (10 MLD) situated close to this study site. Further, $\mathrm{Cu}$ is an important component of pesticide entering to river through agricultural runoff.
Fig. 2 Spatiotemporal variations in concentration $\left(\mu \mathrm{g} \mathrm{g}^{-1}\right)$ of metals in Ganga River sediment
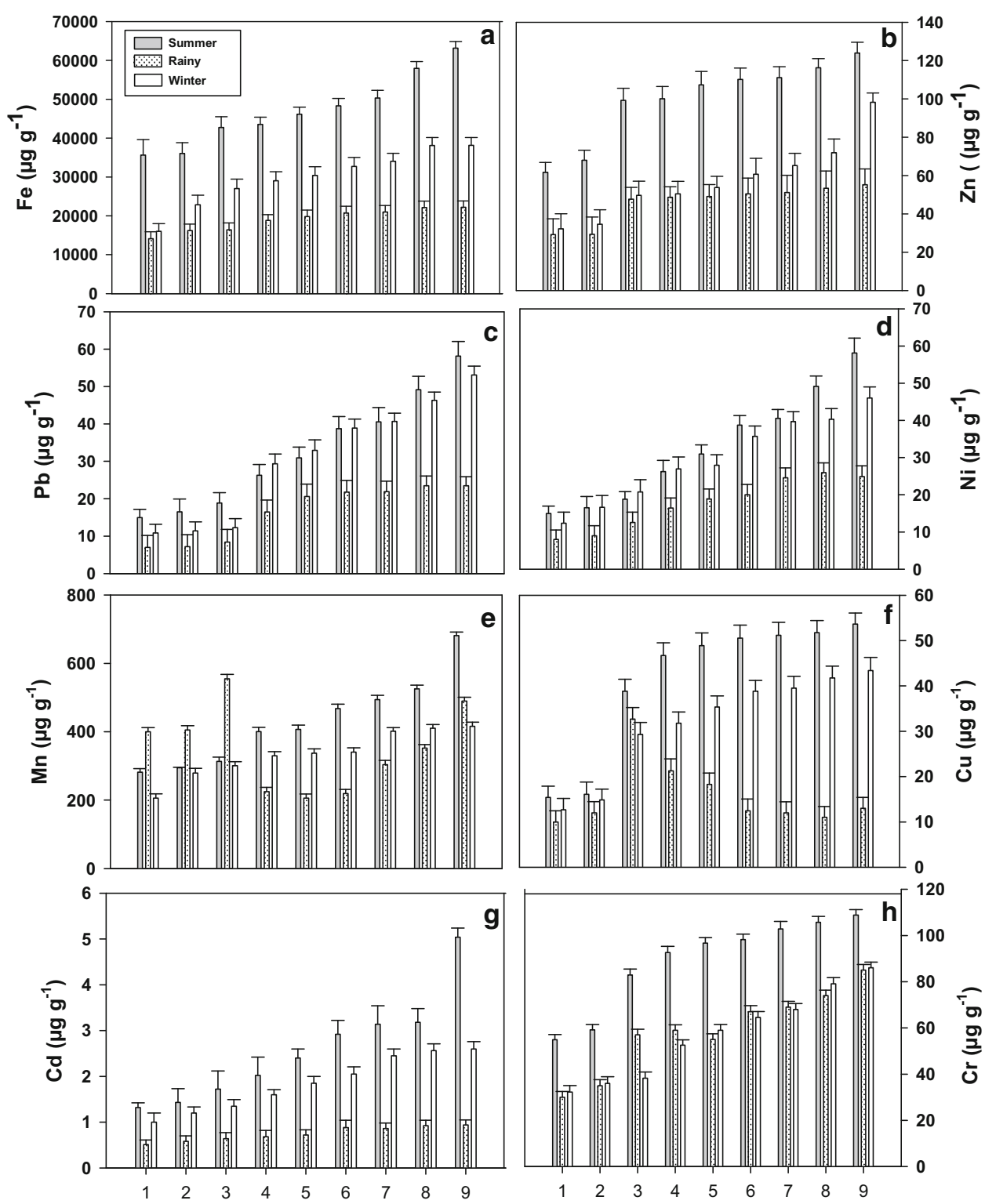

Site 
Table 2 Annual mean $\left(\mu \mathrm{g} \mathrm{g}^{-1}\right)$, percent enrichment, and enrichment factor (EF) for different metals

\begin{tabular}{|c|c|c|c|c|c|c|c|c|c|}
\hline Site no. & & $\mathrm{Fe}$ & $\mathrm{Zn}$ & $\mathrm{Pb}$ & $\mathrm{Ni}$ & $\mathrm{Mn}$ & $\mathrm{Cu}$ & $\mathrm{Cd}$ & $\mathrm{Cr}$ \\
\hline \multirow[t]{3}{*}{1} & Mean & $21,924.07$ & 41.05 & 10.94 & 11.77 & 296.02 & 12.71 & 0.94 & 39.05 \\
\hline & SD & $11,902.05$ & 6.15 & 2.26 & 2.34 & 97.11 & 1.56 & 0.26 & 4.71 \\
\hline & E.F. & - & 0.71 & 0.88 & 0.47 & 0.32 & 0.43 & 3.16 & 0.48 \\
\hline \multirow[t]{3}{*}{2} & Mean & $25,028.80$ & 44.01 & 11.71 & 14.06 & 326.40 & 14.33 & 1.07 & 43.40 \\
\hline & SD & $10,096.72$ & 7.43 & 2.52 & 3.89 & 63.44 & 1.52 & 0.33 & 4.57 \\
\hline & E.F. & - & 0.67 & 0.82 & 0.49 & 0.31 & 0.42 & 3.14 & 0.47 \\
\hline \multirow[t]{3}{*}{3} & Mean & $28,723.93$ & 65.56 & 13.17 & 17.39 & 389.75 & 33.61 & 1.24 & 66.04 \\
\hline & SD & $13,241.11$ & 9.80 & 2.53 & 4.13 & 128.93 & 2.27 & 0.38 & 11.57 \\
\hline & E.F. & - & 0.87 & 0.81 & 0.53 & 0.32 & 0.86 & 3.16 & 0.56 \\
\hline \multirow[t]{3}{*}{4} & Mean & $30,464.93$ & 66.45 & 24.02 & 23.22 & 318.49 & 33.25 & 1.43 & 74.71 \\
\hline & SD & $12,418.66$ & 9.75 & 6.48 & 5.34 & 57.57 & 6.54 & 0.49 & 7.80 \\
\hline & E.F. & - & 0.83 & 1.38 & 0.67 & 0.25 & 0.80 & 3.45 & 0.60 \\
\hline \multirow[t]{3}{*}{5} & Mean & $32,132.67$ & 70.11 & 28.17 & 25.92 & 316.81 & 34.18 & 1.65 & 70.23 \\
\hline & SD & $13,268.96$ & 11.02 & 6.23 & 4.766 & 70.69 & 9.52 & 0.60 & 7.88 \\
\hline & E.F. & - & 0.83 & 1.54 & 0.71 & 0.23 & 0.78 & 3.79 & 0.59 \\
\hline \multirow[t]{3}{*}{6} & Mean & $33,925.07$ & 73.80 & 33.15 & 31.49 & 342.46 & 33.95 & 1.95 & 76.58 \\
\hline & SD & $13,843.86$ & 11.67 & 8.70 & 8.12 & 70.71 & 14.04 & 0.65 & 6.38 \\
\hline & E.F. & - & 0.83 & 1.72 & 0.82 & 0.24 & 0.74 & 4.22 & 0.61 \\
\hline \multirow[t]{3}{*}{7} & Mean & $35,128.93$ & 75.85 & 34.37 & 34.93 & 399.98 & 34.22 & 2.15 & 79.95 \\
\hline & SD & $14,691.92$ & 12.35 & 9.55 & 7.73 & 55.99 & 14.59 & 0.85 & 6.63 \\
\hline & E.F. & - & 0.82 & 1.72 & 0.87 & 0.27 & 0.72 & 4.50 & 0.61 \\
\hline \multirow[t]{3}{*}{8} & Mean & $39,398.87$ & 80.53 & 39.64 & 38.49 & 429.41 & 34.85 & 2.22 & 86.25 \\
\hline & SD & $17,938.39$ & 13.84 & 11.74 & 7.80 & 40.35 & 16.14 & 0.87 & 6.16 \\
\hline & E.F. & - & 0.78 & 1.77 & 0.88 & 0.26 & 0.65 & 4.13 & 0.58 \\
\hline \multirow[t]{4}{*}{9} & Mean & $41,170.13$ & 92.48 & 44.89 & 43.02 & 529.08 & 36.68 & 2.86 & 93.28 \\
\hline & SD & $20,661.64$ & 23.37 & 15.30 & 11.43 & 57.46 & 15.97 & 1.04 & 4.51 \\
\hline & E.F. & - & 0.86 & 1.92 & 0.92 & 0.30 & 0.65 & 5.10 & 0.61 \\
\hline & $\% \mathrm{EF}$ & 52.29 & 51.93 & 46.34 & 47.77 & 32.62 & 71.10 & 40.79 & 56.96 \\
\hline
\end{tabular}

The overall trend in metal concentration was found to be: $\mathrm{Fe}>\mathrm{Mn}>\mathrm{Zn}>\mathrm{Cr}>\mathrm{Cu}>\mathrm{Ni}>\mathrm{Pb}>\mathrm{Cd}$. Almost similar trend has been reported by Ghrefat et al. (2011) at Kafrain dam, Jordan. Iron (Fe) appeared the most abundant element in Ganga River sediment with mean concentration ranging from 21,924 to $41,170 \mu \mathrm{g} \mathrm{g}^{-1}$ (Table 2). Still higher ranges of $\mathrm{Fe}$ have been reported by Biksham et al. (1991) in Godavari River and Singh et al. (2005) in Gomati River receiving anthropogenic release. The Fe abundance in these systems has been attributed, in addition to weathering, erosion and other natural sources, large-scale human activities such as urban-industrial release, municipal solid waste, construction and demolition wastes, and agricultural activities. Concentration of $\mathrm{Zn}$ (41.1-92.6 $\mathrm{mg} \mathrm{g}^{-1}$ ) was found lower than the values (86.1-708.8 $\mu \mathrm{g} \mathrm{g}^{-1}$ ) reported in Almendares River, Cuba (Olivares-Rieumont et al. 2005), receiving industrial release and agricultural wastes (Romic and Romic 2003). Concentration of $\mathrm{Pb}$ reported in this study was comparable to those reported by Singh et al. (2005) in Gomti River.
This metal is mainly associated with $\mathrm{Fe}-\mathrm{Mn}$ oxide fraction and shows high retention in sediments. Domestic sewage, industrial effluents, and vehicular emissions are the major anthropogenic sources of $\mathrm{Pb}$. Concentration of $\mathrm{Ni}$ remained below its baseline $\left(46 \mu \mathrm{g} \mathrm{g}^{-1}\right)$, indicating less polluted condition with respect to this metal. However, a comparison with WHO (2004) and USEPA (1999) threshold values of 20 and $16 \mu \mathrm{g} \mathrm{g}^{-1}$, respectively, indicates that a system with this concentration is considered as a polluted system. $\mathrm{Ni}$ is commonly used in household products such as stainless steel, nonferrous alloys, electroplating, $\mathrm{Ni}-\mathrm{Cd}$ batteries, and coins and thus, there is ample chance of enhanced input of Ni from urban areas. Concentration of $\mathrm{Cu}$ at upstream sites matches with the category of unpolluted status; the values however were found to be higher than WHO norms at downstream sites. Copper is widely used in electrical wiring, roofing, and production of alloys, pigments, cooking utensils, and piping. Further, input of pesticides enhances copper from urban and agricultural areas. Concentrations of $\mathrm{Mn}$ although slightly lower than 
Fig. 3 Significant seasonal trend tested through MannKendall time series analysis with Sen's slope statistics for metal concentration $\left(\mu \mathrm{g} \mathrm{g}^{-1}\right)$ at different sites. S': Sen's estimate; SS: Sen's slope

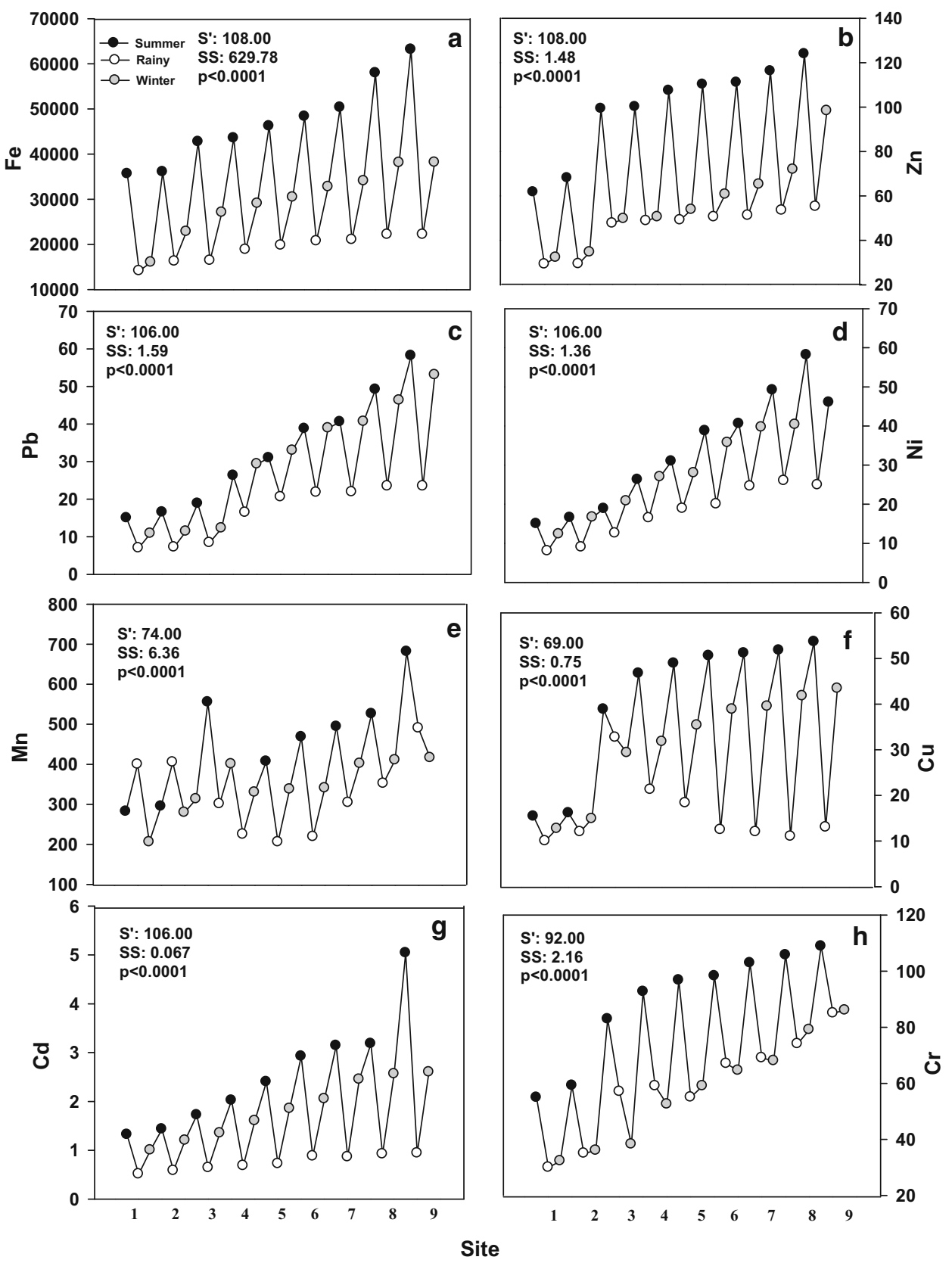

those recorded by Goorzadi et al. (2009) exceeded the USEPA guidelines $\left(30 \mu \mathrm{g} \mathrm{g}^{-1}\right)$. Cadmium was considerably high at all study sites due to urban-industrial and agricultural wastes. Rivers continuously receive trace amount of heavy metals from terrigenous sources such as weathering of rocks. Continuous or intermittent but relatively higher input of heavy metals to rivers and streams is linked to anthropogenic sources such as urban and industrial waste water, fossil fuel combustion, and atmospheric deposition (Sekabira et al. 2010; Pandey et al. 2013; Singh and Pandey 2014). Therefore, heavy metal concentrations in river sediments are used to reveal the history and intensity of local controls. Coupled with over 150 million liters per day (MLD) of untreated sewage entering to the river, sources such as diesel locomotive works, fabrics, textile and dye industries, small- and medium-scale metal industries, and glass and paint industries (DIP 2013) add contaminants to Ganga River. Heavy metals may be immobilized within the river sediments and thus could enter in absorption, co-precipitation, and complex formation processes or they may be co-adsorbed with other elements such as oxides or hydroxides of $\mathrm{Fe}$ and $\mathrm{Mn}$. For instance, $\mathrm{Cd}$ in sediment remains associated with adsorbed, exchangeable, and carbonate (AEC) fraction, thus being 
weakly bound shows intermittent remobilization (Laxen 1985). On the other hand, $\mathrm{Fe}, \mathrm{Mn}, \mathrm{Cr}$, and Ni remain in residual phase, while $\mathrm{Cu}$ as amorphous $\mathrm{Fe}$ oxyhydroxide phases (Sharmin et al. 2010).

Such urban-industrial sources described as above generate strong local control enhancing metal accumulation in sediments particularly from sites 4 to 9 . Such enhancement measured in terms of percent enrichment indicates the amount by which a particular metal has increased from its baseline concentration or a reference value. Granulometry of sediment is an important aspect for understanding dispersion and mobility of heavy metals in river systems. Fine-grained particles act as an efficient scavenger and hence regulate transport and sediment accumulation of heavy metals in rivers and streams (Zonta et al. 1994; Sharmin et al. 2010; Mohiuddin et al. 2010). In the present study, the overall proportion of fine sand was found higher $(>65 \%)$ at all sites. However, at site 4 and downstream, proportions of fine sand were $>80 \%$, indicating the possible association of fine-grained particles with high concentration of heavy metals. Percent enrichment appeared highest for $\mathrm{Cu}(71 \%)$ and lowest for $\mathrm{Mn}(33 \%)$ (Table 2).

Table 3 Comparison of metal $\left(\mu \mathrm{g} \mathrm{g}^{-1}\right)$ in sediments of Ganga River in Varanasi with different standard values

\begin{tabular}{lclll}
\hline Metal & Range & WHO & USEPA & CCME \\
\hline $\mathrm{Fe}$ & $21,924.07-41,170.13$ & - & 30 & - \\
$\mathrm{Zn}$ & $41.05-92.48$ & 123 & 110 & 123 \\
$\mathrm{~Pb}$ & $10.94-44.89$ & - & 40 & 35 \\
$\mathrm{Ni}$ & $11.77-43.02$ & 20 & 16 & - \\
$\mathrm{Mn}$ & $296.02-529.08$ & - & 30 & - \\
$\mathrm{Cu}$ & $12.71-36.68$ & 25 & 16 & 35.7 \\
$\mathrm{Cd}$ & $0.94-2.86$ & 0.6 & 0.6 & 0.6 \\
$\mathrm{Cr}$ & $39.05-93.28$ & 25 & 25 & 37.3 \\
\hline
\end{tabular}

WHO world health organization, USEPA US environment protection agency, $C C M E$ Canadian water quality guidelines for protection of aquatic life
Singh et al. (2005) showed a comparable enrichment of $\mathrm{Cu}$ and $\mathrm{Mn}$ in the sediment of Gomati River. We also calculated enrichment factor (EF) used to predict the level of contamination and possible anthropogenic impact on the sediment (Esen et al. 2010). A metal with EF between 0.5 and 1.5 is considered in a crustal state, whereas EF $>1.5$ indicates anthropogenic disturbances (Zhang and Liu 2002). In this study, except for $\mathrm{Cd}$ and $\mathrm{Pb}$, the $\mathrm{EF}$ remained $<1$, indicating relatively smaller enrichment (Table 2). A comparison of our data with Chen et al. (2007) indicates $\mathrm{Cd}$ at Rajghat (site 9) has moderate to severe enrichment, and at sites 4, 5, 6, and 7, it has moderate enrichment. Lead $(\mathrm{Pb})$ at sites 5, 6, 7, 8, and 9 showed small to moderate enrichments. Ghrefat et al. (2011) and Singh et al. (2005) also showed high enrichment of $\mathrm{Pb}$ and $\mathrm{Cd}$ in sediments receiving anthropogenic influences. When compared with USEPA (1999) and CCME (1999) (Canadian Water Quality Guidelines for Protection of Aquatic Life), concentrations of all the metals except $\mathrm{Zn}$, in most of the cases, were found higher than the threshold values (Table 3). Concentrations although remained below the world averages (Martin and Meybeck 1979) (Table 4) of $\mathrm{Cd}, \mathrm{Ni}, \mathrm{Cu}$, and $\mathrm{Cr}$ did exceed WHO (2004) standards. Accumulation of $\mathrm{Zn}$ in Ganga River was found higher than those reported in Tapti River (Marathe et al. 2011), and $\mathrm{Pb}, \mathrm{Cu}$, and $\mathrm{Cr}$ were higher than those reported in Cauvery (Raju et al. 2012) and Euphrates River (Salah et al. 2012). These observations indicate relatively higher input of heavy metals in Ganga River in Varanasi region.

It was found that there exists positive correlation $\left(R^{2}=0.31-0.93 ; p<0.05-0.01\right)$ between organic carbon (OC) and study metals. Metal pairs such as $\mathrm{Fe}-\mathrm{Zn}, \mathrm{Pb}-\mathrm{Fe}$, $\mathrm{Pb}-\mathrm{Zn}, \mathrm{Ni}-\mathrm{Fe}, \mathrm{Ni}-\mathrm{Zn}, \mathrm{Ni}-\mathrm{Pb}, \mathrm{Cd}-\mathrm{Fe}, \mathrm{Cd}-\mathrm{Zn}, \mathrm{Cd}-\mathrm{Pb}, \mathrm{Cd}-$ $\mathrm{Ni}, \mathrm{Cd}-\mathrm{Mn}, \mathrm{Cr}-\mathrm{Fe}, \mathrm{Cr}-\mathrm{Zn}, \mathrm{Cr}-\mathrm{Pb}, \mathrm{Cr}-\mathrm{Ni}$, and $\mathrm{Cr}-\mathrm{Cd}$ also showed significant positive relationships (Table 5). Relationship with organic carbon indicates possible chelation (Jayaprakash et al. 2008) while those between metal pairs show common sources of origin or similarity in geochemical behavior. Similar observations have been made by Dhanakumar et al. (2011) and Kumar et al. (2013).

Table 4 Comparison of average concentration of heavy metals in sediment of Ganga River with other world rivers

\begin{tabular}{llllllllll}
\hline River & \multicolumn{3}{l}{ Concentration $\left(\mu \mathrm{g} \mathrm{g}^{-1}\right)$} & & & & \multicolumn{2}{c}{ References } \\
\cline { 2 - 7 } & $\mathrm{Fe}$ & $\mathrm{Zn}$ & $\mathrm{Pb}$ & $\mathrm{Ni}$ & $\mathrm{Mn}$ & $\mathrm{Cu}$ & $\mathrm{Cd}$ & $\mathrm{Cr}$ & \\
\hline Ganga River & $31,988.6$ & 67.8 & 26.7 & 26.7 & 372.0 & 29.8 & 1.7 & 69.9 & Present study \\
Cauvery, India & 11,144 & 93.1 & 4.3 & 27.7 & 176.3 & 11.2 & 1.3 & 38.9 & Raju et al. (2012) \\
Tapti, India & $1.9-5.7$ & $1.2-6.1$ & - & - & $6-8.9$ & $0.5-4.1$ & - & - & Marathe et al. (2011) \\
Yangtze, China & - & 230.4 & 49.2 & 41.9 & - & 60.03 & 1.0 & 108.0 & Wang et al. (2011) \\
Buriganga, Bangladesh & - & 502.3 & 79.8 & - & - & 184.4 & 0.8 & 101.2 & Saha and Hossain (2010) \\
Euphrates, Iraq & 2249.5 & 48.0 & 22.6 & 67.1 & 228.2 & 18.9 & 1.9 & 58.4 & Salah et al. (2012) \\
World average & $57,405.9$ & 303 & 230.8 & 102.1 & 975.3 & 122.9 & 1.4 & 126 & Martin and Meybeck (1979) \\
\hline
\end{tabular}


Table 5 Correlation between metal pairs and with organic carbon in the river sediment

\begin{tabular}{|c|c|c|c|c|c|c|c|c|c|}
\hline & $\mathrm{Fe}$ & $\mathrm{Zn}$ & $\mathrm{Pb}$ & $\mathrm{Ni}$ & $\mathrm{Mn}$ & $\mathrm{Cu}$ & $\mathrm{Cd}$ & $\mathrm{Cr}$ & $\mathrm{OC}$ \\
\hline $\mathrm{Fe}$ & 1 & & & & & & & & \\
\hline $\mathrm{Zn}$ & $0.97 * *$ & 1 & & & & & & & \\
\hline $\mathrm{Pb}$ & $0.97 * *$ & $0.92 * *$ & 1 & & & & & & \\
\hline $\mathrm{Ni}$ & $0.98 * *$ & $0.94 * *$ & $0.99 * *$ & 1 & & & & & \\
\hline $\mathrm{Mn}$ & $0.79 *$ & $0.78^{*}$ & $0.71 *$ & $0.77 *$ & 1 & & & & \\
\hline $\mathrm{Cu}$ & 0.59 & $0.73^{*}$ & 0.43 & 0.48 & 0.46 & 1 & & & \\
\hline $\mathrm{Cd}$ & $0.96 * *$ & $0.93 * *$ & $0.97 * *$ & $0.98 * *$ & $0.84 * *$ & 0.46 & 1 & & \\
\hline $\mathrm{Cr}$ & $0.96 * *$ & $0.99 * *$ & $0.92 * *$ & $0.93 * *$ & $0.72 *$ & $0.73 *$ & $0.90 * *$ & 1 & \\
\hline $\mathrm{OC}$ & $0.78 *$ & $0.77 *$ & $0.77 *$ & $0.78 *$ & $0.93 * *$ & 0.31 & $0.87 * *$ & $0.70 *$ & 1 \\
\hline
\end{tabular}

Pearson correlation (two-tailed): * $p<0.05$; ** $p<0.01$

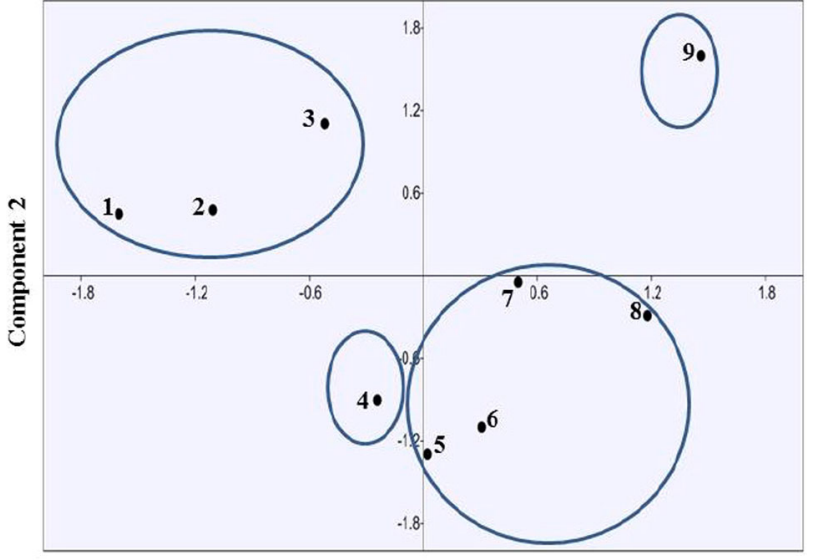

Component 1

Fig. 4 Principal component analysis (PCA) ordinates with sites 1-9 representing Chunar, Adalpura, Ramna Ghat, Gadwa Ghat, Ravidas Park, Assi Ghat, Dashashwamedh Ghat, Manikarnika Ghat, and Rajghat, respectively

Principal component analysis (PCA) was used to identify principal drivers regulating spatial and temporal distribution patterns of heavy metals in the river sediments. This multivariate technique analyzes the interrelations between explanatory variables and response variables and extracts principal drivers by reducing the contribution of factors with minor significance. The PCA ordinates segregated sites into four groups. Relatively less polluted sites such as Chunar, Adalpura, and Ramna appeared in one group (Fig. 4). Gadwa, which receives higher pollution input than the first three upstream sites, appeared separate from the rest of the sites. This site receives, in addition to surfaceborne inputs, massive amount of atmospherically deposited materials from the bypass highway. The analysis separates Ravidas Ghat, Assi Ghat, Dashashwamedh Ghat, and Manikarnika Ghat as third group showing the influence of urban release in downstream contamination. The most polluted site Rajghat did appear separately indicating the influence of urban input and downstream factors.

\section{Conclusions}

The overall results of this study show that heavy metal concentration in river sediment is rising. Spatial distribution showed different degrees of pollution and a consistently rising trend downstream, indicating strong influence of local sources including agricultural and untreated urbanindustrial wastewater. A number of micro- and macrodrains add untreated urban-industrial wastewater in the river at different points along the city. These drains need to be checked and wastewater to be properly treated. Metal concentration showed the influence of seasonal pattern in hydrological discharge. Among the metals, $\mathrm{Cd}$ and $\mathrm{Pb}$ exceed their base levels and show moderate to severe enrichment downstream, suggesting the role of local factors and the need to screen sources of such metals to the river for adopting appropriate control measures. Since $\mathrm{Cd}$ mainly remains AEC-bound and has high mobility and bioavailability, the data indicate that the Ganga River posses high risk for $\mathrm{Cd}$. The study provides important database for future research on Ganga River and for designing control measures and action plan for river basin management.

Acknowledgments The authors are thankful to the Coordinator, Centre of Advanced Study in Botany, for facilities and to Banaras Hindu University for financial support.

Open Access This article is distributed under the terms of the Creative Commons Attribution 4.0 International License (http:// creativecommons.org/licenses/by/4.0/), which permits unrestricted use, distribution, and reproduction in any medium, provided you give appropriate credit to the original author(s) and the source, provide a link to the Creative Commons license, and indicate if changes were made. 


\section{References}

Biksham G, Subramanian V, Ramanathan AL, Grieken RV (1991) Heavy metal distribution in the Godavari River basin. Environ Geol Water Sci 17(2):117-126

CCME (1999) Canadian water quality guidelines for protection of aquatic life, technical report, Canadian environmental quality guidelines, Canadian water quality index 1.0

Chen CW, Kao CM, Chen CF, Dong CD (2007) Distribution and accumulation of metals in sediments of Kaoshiung Harbor, Taiwan. Chemosphere 66:1431-1440

Copaja SV, Molina X, Tessada R (2014) Determination of heavy metals in Choapa River sediments using BCR sequential extraction procedure. J Chil Chem Soc 59(1):2353-2358

Dhanakumar S, Mani S, Murthy RC, Veeramani M, Mohanraj R (2011) Heavy metals and their fractionation profile in surface sediments of upper reaches in the Cauvery. Int J Geol Earth Environ Sci $1: 38-47$

District Industrial Profile (DIP) (2013) Varanasi. Ministry of micro, small and medium interprises, Government of India

Esen E, Kucuksezgin F, Uluturhan E (2010) Assessment of trace metal pollution in surface sediments of Nemrut Bay, Aegean Sea. Environ Monit Assess 160:257-266

Ghrefat HA, Abu-Rukah Y, Rosen MA (2011) Application of geo accumulation index and enrichment factor for assessing metal contamination in sediments of Kafrain Dam, Jordan. Environ Monit Assess 178:95-109

Goorzadi M, Vahabzadeh GH, Ghanbarpour MR, Karbassi AR (2009) Assessment of heavy metal pollution in Tilehbon River sediments, Iran. J Appl Sci 9:1190-1193

Jayaprakash M, Jonathan MP, Srinivasalu S, Muthuraj S, Ram-Mohan V, Rajeshwara-Rao N (2008) Acid-leachable trace metals in sediments from an industrialized region (Ennore Creek) of Chennai City, SE coast of India: an approach towards regular monitoring. Estuar Coast Shelf Sci 76:692-703

Kumar RN, Solanki R, Kumar JN (2013) Seasonal variation in heavy metal contamination in water and sediments of river Sabarmati and Kharicut canal at Ahmedabad, Gujrat. Environ Monit Assess 185:359-368

Laxen DPH (1985) Trace metal adsorption/co-precipitation of hydrous ferric oxide under realistic conditions. Water Res 19:1229-1236

Marathe R, Marathe Y, Sawant C, Shrivastava V (2011) Detection of trace metals in surface sediment of Tapti River: a case study. Arch Appl Sci Res 3(2):472-476

Martin J, Meybeck M (1979) Elemental mass-balance of material carried by major world rivers. Mar Chem 7(3):178-206

Mohiuddin KM, Zakir HM, Otomo K, Sharmin S, Shikazona N (2010) Geochemical distribution of trace metal pollutants in water and sediments of downstream of an urban river. Int $\mathbf{J}$ Environ Sci Technol 7:108-118

Mucha AP, Vasconcelos MTSD, Bordalo AA (2003) Macrobenthic community in the Doura estuary: relations with trace metals and natural sediment characteristics. Environ Pollut 121:169-180

Olivares-Rieumont S, Rosa DL, Graham L, Alessandro DW, Borroto KD, Martinez JF, Sanchez J (2005) Assessment of heavy metal levels in Almendares River sediments-Havana City, Cuba. Water Res 39:3945-3953

Osakwe JO, Adowei P, Jnr MH (2014) Evaluation of heavy metal species in bottom sediments from Imo River system, Southeastern Nigeria. Res J Chem Sci 4(6):23-30

Pandey J, Shubhashish K, Pandey R (2010) Heavy metal contamination of Ganga River at Varanasi in relation to atmospheric deposition. Trop Ecol 51:365-373

Pandey J, Singh AV, Singh A, Singh R (2013) Impact of changing atmospheric deposition chemistry on nitrogen and phosphorous loading to Ganga River. Bull Environ Contam Toxicol 91:184-190

Pehlivan E, Ozkan AM, Dinç S, Parlayici S (2009) Adsorption of $\mathrm{Cu}^{2+}$ and $\mathrm{Pb}^{2+}$ ion on Dolomite powder. $\mathrm{J}$ Hazard Mater 167(13):1044-1049

Raju KV, Somashekar R, Prakash K (2012) Heavy metal status of sediment in river Cauvery, Karnataka. Environ Monit Assess 184(1):361-373

Ramesh R, Subramanian V, Grieken RV (1990) Heavy metal distribution in sediments of Krishna River basin. Environ Geol Water Sci 15:207-216

Romic M, Romic D (2003) Heavy metals distribution in agricultural top soils in urban area. Environ Geol 43:795-805

Rzetala MA (2015) Assessment of toxic metal contamination of bottom sediments in water bodies in urban areas. Soil Sediment Contam Int J 24(1):49-63

Saha P, Hossain M (2010) Assessment of heavy metal concentration and sediment quality in the Buriganga River, Bangladesh. In: International proceedings of chemical, biological and environmental engineering, Singapore City, pp VI-384-VI-387

Salah EAM, Zaidan TA, Al-Rawi AS (2012) Assessment of heavy metals pollution in the sediments of Euphrates River, Iraq J Water Res Prot 4:1009-1023

Sekabira K, Origa HO, Basamba TA, Mutumba G, Kabudidi E (2010) Assessment of heavy metal pollution in the urban stream sediments and its tributaries. Int J Environ Sci Technol 7:435-446

Sharmin S, Zakir HM, Shikazono N (2010) Fraction profile and mobility pattern of trace metals in sediments of Nomi River, Tokyo. J Soil Sci Environ Manag 1:1-14

Singh IB (1996) Geological evolution of Ganga plain —an overview. J Palaeontol Soc India 41:99-137

Singh A (2012) Environmental impacts of atmospheric deposition of nutrients and trace elements on selected vegetable crops under organic farming. Ph.D. thesis, Banaras Hindu University, India

Singh AV, Pandey J (2014) Heavy metals in the midstream of the Ganges River: spatio-temporal trends in a seasonally dry tropical region (India). Water Int 39(4):504-516

Singh M, Ansari AA, Muller G, Singh IB (2003) Geogenic distribution and baseline concentration of heavy metals in sediment of Ganges River, India. J Geochem Explor 80:1-17

Singh VK, Singh KP, Mohan D (2005) Status of heavy metals in water and bed sediments of river Gomti-a tributary of the Ganga River, India. Environ Monit Assess 105:43-67

Turekian KK, Wedepohl KH (1961) Distribution of elements in some major units of the earth's crust. Geol Soc Am Bull 72:175-192

USEPA (1999) US Environmental Protection Agency: screening level ecological risk assessment protocol for hazardous waste combustion facilities. Appendix E: toxicity reference values, 3

Vukovic D, Stankovic SJ, Vukovic Z, Jankoviv K (2014) Transport and storage of heavy metals in the Sava River Basin in Serbia. J Serbian Chem Soc 79(3):379-387

Walkley A, Black CA (1947) A critical examination of a rapid method for determining organic carbon in soils: effect of variations in digestion conditions and of inorganic soil constituents. Soil Sci 63:251-263

Wang Y, Yang Z, Shen Z, Tang Z, Niu J, Gao F (2011) Assessment of heavy metals in sediments from a typical catchment of the Yangtze River, China. Environ Monit Assess 172(1-4):407-417

WHO (2004) Guidelines for drinking water quality. World Health Organization, Geneva, p 515

Zhang J, Liu CL (2002) Riverine composition and estuarine geochemistry of particulate metals in China-weathering features, anthropogenic impact and chemical fluxes. Estuar Coast Shelf Sci 54:1051-1070

Zonta R, Zaggia L, Argrse E (1994) Heavy metal and grain size distributions in estuarine shallow water sediments of the Cona Marsh (Venice Lagoon, Italy). Sci Total Environ 15:19-28 